\title{
FOREIGN JUDGMENTS BASED ON FOREIGN ARBITRAL AWARDS: THE APPLICABILITY OF RES JUDICATA
}

\section{INTRODUCTION}

On September 30, 1970, the United States formally acceded to the Convention on the Recognition and Enforcement of Foreign Arbitral Awards, ${ }^{1}$ following congressional enactment of implementing legislation ${ }^{2}$ considered by the Johnson administration to be essential to meeting our responsibilities under the agreement. ${ }^{3}$ In acceding, the United States declared that it would apply the Convention only to awards "made in the territory of another Contracting State," and then only to "differences ... which are considered as commercial under the national law of the United States." 4 Thus, after twelve years of official indecision, ${ }^{5}$ this country opened its judicial doors to the fruits of one of the outside world's primary means of dispute settlement-commercial arbitration.

Although the implementing legislation makes clear that the treatment of awards under the Convention is a matter of federal

${ }^{1}$ Convention on the Recognition and Enforcement of Foreign Arbitral Awards, Sept. 30, 1970, [1970] 3 U.S.T. 2517, T.I.A.S. No. 6997, 330 U.N.T.S. 38 (effective Dec. $29,1970)$ [hereinafter cited as Convention]. The text of the Convention can also be found after 9 U.S.C.A. $\S 201$ (Supp. 1975). On accession, the United States extended the Convention to "all the territories for the international relations of which the United States of America is responsible," effective February 1, 1971. [1970] 3 U.S.T. 2560.

${ }^{2}$ Act of July 31,1970 , Pub. L. No. 91-368, § 1, 84 Stat. 692 (codified at 9 U.S.C. $\S \S 201-08$ (1970)).

${ }^{3}$ S. Exec. Doc. E, 90th Cong., 2d Sess. 1, 5 (1968); S. Exec. ReP. No. 10, 90th Cong., 2d Sess. 2, 5-6 (1968).

${ }^{4}$ [1970] 3 U.S.T. 2560.

5 The Convention was opened for signature on June 10, 1958. Final Act of the United Nations Conference on International Commercial Arbitration, June 10, 1958, 330 U.N.T.S. 4, 8. In accordance with article XII, the Convention came into force on June 7, 1959. 330 U.N.T.S. 38 n.1. The reasons for the delay in United States accession included uncertainties about the international and business support for the Convention, the possible effects on state arbitration law, and the unclear constitutional status of federal arbitration law under traditional interpretations of 9 U.S.C. $\$ \S 1-14$ (1970). S. ExEc. REP. No. 10, 90th Cong., 2d Sess. 6-8 (1968). The concern over the degree of support proved unfounded. S. Exec. Doc. E, 90th Cong., 2d Sess. 27-44 (1968). The legal questions were eventually resolved as a majority of the states adopted a more, liberal approach to arbitration agreements, and the Supreme Court consigned the implementation of title 9 to the "federal common law" in Prima Paint Corp. v. Flood \& Conklin Mfg. Co., 388 U.S. 395 (1967). S. Exec. Rep. No. 10, 90th Cong., 2d Sess. 6-8 (1968). 
law, neither the treaty nor the legislation deals with the treatment of a judgment rendered by a foreign tribunal on an arbitral award as a result of a prior enforcement effort. As will be shown, a significant number of awards under the Convention will enter the United States for enforcement accompanied by foreign judgments. The courts will naturally be faced with the question whether the doctrine of merger, an element of res judicata, is applicable to arbitral awards and foreign judgments based thereon.

After demonstrating the likelihood that foreign arbitral awards will reach the United States accompanied by foreign judgments, and after examining the evolving treatment of foreign judgments ${ }^{6}$ in American courts, this Comment will discuss the policies that should lead the courts to refuse to merge foreign arbitral awards into foreign judgments based thereon.

\section{BACKGROUND}

\section{A. The Convention and Its Statutory Implementation}

The Convention on the Recognition and Enforcement of Foreign Arbitral Awards ${ }^{7}$ requires that a contracting state "recognize arbitral awards as binding and enforce them in accordance with the rules of procedure of the territory where the award is relied upon," without imposing "substantially more onerous conditions or higher fees or charges" for actions on foreign awards under the Convention than it would for actions on "domestic" awards. ${ }^{8}$

To fulfill this duty, the courts of a contracting state must

${ }^{6}$ As used throughout this Comment, the term "foreign" will refer only to proceedings external to the United States. The term "sister-state" will be used to refer to actions in one of the fifty states based on proceedings in another.

${ }^{7}$ For discussions of the Convention as a whole, see Contini, International Commercial Arbitration, 8 AM. J. Comp. L. 283 (1959); Domke, The United Nations Conference on International Commercial Arbitration, 53 AM. J. INT'L L. 414 (1959); Pisar, The United Nations Convention on Foreign Arbitral Awards, 1959 J. Bus. L. 219; Quigley, Accession by the United States to the United Nations Convention on the Recognition and Enforcement of Foreign Arbitral Awards, 70 Yale L.J. 1049 (1961); Sanders, New York Convention on the Recognition and Enforcement of Foreign Arbitral Awards, 6 Nederlands TIJDSChrift voor INTERNATIONAal ReCHT 43 (1959); Springer, The United Nations Convention on the Recognition and Enforcement of Foreign Arbitral Awards, 3 INT'L LAwYER 320 (1969). For an encapsulated but thorough exposition of the negotiating history of the Convention, see G. HaIGHT, Convention on the Recognition and Enforcement of Foreign Arbitral Awards (1958).

${ }^{8}$ Convention, art. III. 
enforce an arbitral award unless the award falls within one of the eight grounds for nonenforcement, including (1) nonarbitrability of the subject matter of the award under the law of the enforcing nation;: (2) nonfinality of the award; ${ }^{10}$ and (3) violation of the public policy of the enforcing nation. ${ }^{11}$

The legislation implementing the treaty ${ }^{12}$ eliminates jurisdictional hurdles to the enforcement of foreign arbitral awards by creating federal question jurisdiction without a jurisdictional amount, and by vesting in the district courts original jurisdiction of actions under the Convention. ${ }^{13}$ It also provides for liberal removal from state court to federal court ${ }^{14}$ and requires that an award be enforced within three years unless one of the specified grounds for refusal of enforcement is satisfied. ${ }^{15}$

${ }^{9}$ Id., art. V, para. 2(a).

${ }^{10} I d$., art. V, para. $1(\mathrm{e})$.

${ }^{11}$ Id., art. V, para. 2(b). Enforcement may also be refused when: (1) the parties to the arbitration were under some incapacity, id., art. V, para. 1(a); (2) the arbitration agreement is invalid, $i d . ;(3)$ the party against whom the award is invoked was not given proper notice before rendition or was unable to present his case, $i d$. , art. V, para. 1(b); (4) the award does not comply with the expectations of the parties concerning the scope of the agreement to arbitrate, id., art. V, para. 1(c); and (5) the composition of the tribunal or the procedure it followed was not in accordance with the agreement of the parties or with the law of the country where the arbitration took place, id., art. V, para. l(d).

129 U.S.C. $\$ \S 201-08$ (1970). By far the most penetrating analysis of the implementing legislation is found in McMahon, Implementation of the United Nations Convention on Foreign Arbitral Awards in the United States, 2 J. MAR. L. \& CoM. 735 (1971) (reprinted without footnotes in 26 ARB. J. (n.s.) 65 (1971)). For other treatments, see Aksen, American Arbitration Accession Arrives in the Age of Aquarius: United States Implements United Nations Convention on the Recognition and Enforcement of Foreign Arbitral Awards, 3 Sw. U.L. REv. 1 (1971); Domke, The United States Implementation of the United Nations Arbitral Convention, 19 AM. J. Comp. L. 575 (1971); Evans \& Ellis, International Commercial Arbitration: A Comparison of Legal Regimes, 8 TEXAS INT'L L.J. 17 (1973); Quigley, Convention on Foreign Arbitral Awards, 58 A.B.A.J. 821 (1972); Comment, International Commercial Arbitration Under the United Nations Convention and the Amended Federal Arbitration Statute, 47 WASH. L. REv. 441 (1972). It is interesting to compare the amendments to title 9, 9 U.S.C. $\$ \S 201-08$ (1970), with the legislation suggested in Quigley, supra note 7, at 1079-82.

139 U.S.C. $\S 203$ (1970). One commentator has argued that, read as a whole, the amendments to title 9, 9 U.S.C. $\$ \$ 201-08$ (1970), create exclusive federal jurisdiction. McMahon, supra note 12, at 746-47. This was the approach advocated in Quigley, supra note 7, at 1081-82. It would seem, however, that if Congress had wanted to create exclusive federal jurisdiction, it could have found the words to do so. See, e.g., 15 U.S.C. $\S 78 \mathrm{aa}(1970)$.

149 U.S.C. § 205 (1970). Liberal removal from state to federal court is a realistic response to the, multifarious means by which an arbitration award may be introduced into ongoing litigation that, but for the Convention, would have no place in federal court. Section 205 absorbs the procedures embodied in the general removal statutes, 28 U.S.C. $\$ \S 1446-49$ (1970), "except that the ground for removal . . need not appear on the face of the complaint but may be shown in the petition for removal."

${ }^{15} 9$ U.S.C. § 207 (1970). See notes $9-11$ supra \& accompanying text. 
B. The Likelihood that Foreign Arbitral Awards Entering the United States for Enforcement Will Be Accompanied by Foreign Judgments

In view of this Comment's thesis that foreign judgments on arbitral awards present a substantial problem for judicial resolution, it is appropriate to demonstrate that the problem is likely to arise. As a matter of law, the prevailing party to an arbitration need not reduce his award to a judgment in the rendering nation before seeking enforcement. ${ }^{16}$ As a matter of self-interest, however, the procedural attributes of foreign arbitration laws and the practical effect of a judgment suggest that the prevailing party to an arbitration is likely to have sought enforcement in the rendering nation before coming to the United States.

Consider first the procedural factor. If the losing party has a potentially valid claim that the procedure or award is illegal, the one recourse generally available ${ }^{17}$ to him under the laws of the contracting states is a motion to set aside the award in the local court of competent jurisdiction. ${ }^{18}$ The grounds for setting aside an award are similar to the grounds for refusing to enforce an award under the Convention. ${ }^{19}$

The procedural advantage to the plaintiff who obtains a judgment on his award stems from the fact that in some countries, a judicially confirmed award is almost immune from a motion to set aside. ${ }^{20}$ Moreover, in many countries the filing of a motion to execute or the entering of an execution order begins the running of the statute of limitations for the motion to set aside. ${ }^{21}$ Accordingly, in order to cut off his opponent's rights or

${ }^{16}$ One of the primary goals of the drafting conference was to give the arbitral award a force of its own, without the requirement of a judgment thereon in the rendering country. See G. HaIGHT, supra note 7, at 39-44. Although the language of the Convention may not convey this consensus, art. V, para. 1(e), the negotiating history of the Convention is clear on the intent of the drafters. See G. HaIGHT, supra note 7, at 33-34.

${ }^{17}$ A summary of the arbitration laws of 67 countries can be found in INTERNatronal Chamber of Commerce, Commercial arbitration and the Law Throughout the WORLD (1964) [hereinafter cited as ICC].

${ }^{18}$ There are some exceptions. In Mexico, appeal is the only recourse open to the losing party. Id., Mexico 6. In the Soviet Union, awards of the semi-official Arbitration Commission are unassailable on rendition. Id., U.S.S.R. 6.

${ }^{19}$ Compare C. Pro. Civ. art. 1028 (69e ed. Petits Codes Dalloz 1973) (Fr.); ZPO $\S 1041$ (Baumbach-Lauterbach 1970) (W. Ger.); Indian Arbitration Act of $1940 \S 30$; Arbitration Law of July 30, 1968, ch. 5, § 24, 22 LAws of THE STATE of IsRAEL 210 (off. trans. 1968); C. Grv. Pro. art. 801 (EHS L. Bull. Ser. 1972) (Japan); ICC, supra note 17, Netherlands 6, with notes 9-11 supra and accompanying text.

${ }^{20}$ See, e.g., the Israeli arbitration law, Arbitration Law of July 30, 1968, ch. 5, § 27(c), 22 LAWS OF THE STATE OF ISRAEL 210 (off. trans. 1968), and the Japanese arbitration law, C. Crv. Pro. arts. 799-804 (EHS L. Bull. Ser. 1972).

${ }^{21}$ In France, the limitation period of one month begins to run only on execution. 
at least to begin the running of the limitation period, the successful party to a foreign arbitration is likely to seek judicial confirmation as a matter of course. ${ }^{22}$

Even absent these procedural considerations, the prevailing party would likely be persuaded to seek enforcement in the rendering country by three practical effects of the judgment. First, as noted above, ${ }^{23}$ the courts of a contracting state may refuse recognition and enforcement of an award if the award is not yet "binding on the parties."24 Although the negotiating history of the Convention makes it clear that the word "binding" was not intended to make an award unenforceable absent a judgment thereon, ${ }^{25}$ a judgment, in addition to presenting the enforcing court with a neater package, will resolve the question of binding effect for even the most skeptical court. ${ }^{26}$

Second, by forcing the losing party to interpose his motion to set aside the award before foreign enforcement is sought, the prevailing party can avoid both the inconvenience of litigating in two countries at the same time and the delay in enforcement that may result when a mation to suspend or set aside is pending. ${ }^{27}$

Finally, if in selecting the law to govern the arbitration (a choice vested in the parties under the Convention) ${ }^{28}$ the parties have made the likely choice of the law of the rendering nation, ${ }^{29}$ a judgment for the prevailing party may limit, and possibly even eliminate, the opportunities for the enforcing court to misapply the foreign law. By moving for execution, the prevailing party forces his adversary to make, and the court in the rendering nation to decide, a motion to set aside; the grounds for a motion

Decree of Aug. 28, 1972, arts. 66, 78, [1972] J.O. 9300, [1972] D.S.L. 475. In Israel, the period of 45 days runs from the date of rendition of the award. Arbitration Law of July 30,1968 , ch. 5, \& 27(a), 22 LAws of THE STATE OF IsRAEL 210 (off. trans. 1968). In Japan, execution carries the Israeli consequences. C. Civ. Pro. art. 802(2) (EHS L. Bull. Ser. 1972).

${ }_{22}$ It should be noted that procedurally, there are no disincentives to seeking execution. In many countries, the filing of the award with the appropriate court is often beyond the control of the parties. See, e.g., C. Pro. Civ. art. $1020(69 \mathrm{e}$ ed. Petits Codes Dalloz 1973) (Fr.); C. Grv. PRo. art. 799(2) (EHS L. Bull. Ser. 1972) (Japan); ICC, supra note 17, Netherlands 4 . Even where the parties must file the award, however, the burden of formalization is largely borne by the arbitrators. See, e.g., Arbitration Law of July 30, 1968, ch. 5, § 27(d), 22 Laws OF THE State of IsRael 210 (off. trans. 1968).

${ }^{23}$ Text accompanying note 9 supra.

${ }^{24}$ Convention, art. V, para. 1(e).

${ }^{25}$ See note 16 supra.

${ }^{26}$ See In re Fotochrome, Inc., 377 F. Supp. 26, 29-30 (E.D.N.Y. 1974).

${ }^{27}$ Convention, art. VI.

${ }^{28}$ See, e.g., id., art. V, para. 1(a).

${ }^{29}$ This choice is likely because it is the law with which the arbitrators will be most familiar and thus least likely to err. 
to set aside, however, may be similar or even identical to those for nonenforcement under the Convention. ${ }^{30}$ The Convention requires the enforcing court to apply the law of the rendering nation in deciding whether there are any grounds for nonenforcement. To the extent that these issues are litigated on the motion to set aside the award, the plaintiff will have evidence of how the rendering nation's law would be applied by that nation's courts to the given facts. ${ }^{31}$ Even if all of the foreign-law issues that could be raised under the Convention were not litigated on the motion to set aside, the prevailing party would still be closer to enforcement by the number of such issues that were litigated.

Given the practical implications of a judgment and the procedural considerations discussed above, the prevailing party confident of the legal validity of his award ${ }^{32}$ will have a strong inducement to seek foreign execution before coming to the United States. It appears, therefore, that many, if not most, awards entering the United States for enforcement will be accompanied by foreign judgments.

\section{The Relevance of State Law to the Treatment of Foreign Judgments Based upon Arbitral Awards Under the Convention}

In Klaxon Co. v. Stentor Electric Manufacturing Co., ${ }^{33}$ the Supreme Court extended the holding of Erie R.R. v. Tompkins ${ }^{34}$ to the choice of law rules of the state in which a federal court sits. In diversity cases, therefore, a federal court will apply its state's rules of conflict of laws-an area of jurisprudence normally viewed as including the treatment accorded foreign and sisterstate judgments. ${ }^{35}$ Shortly after the Klaxon decision, a federal

${ }^{30}$ See note 19 supra \& accompanying text.

${ }^{31}$ Of course, if the losing party did not make the motion to set aside, this result would not follow. By not making the motion to set aside before the prevailing party's motion for execution is decided, however, the losing party would likely waive his right ever to make it. See note 21 supra \& accompanying text.

${ }^{32}$ If the prevailing party is not confident of the validity of his award, it is arguable that he would be wiser to avoid the courts of the country whose law applies to the award and to hope instead for a misapplication of that law by the enforcing court. This tendency to avoid a judgment is mitigated by two factors: (1) if the prevailing party in the arbitration is not forever barred, he may prefer to settle the matter at home without a trip abroad; and (2) at some point along the continuum of validity, the losing party will, in all probability, seek judicial action himself.

33313 U.S. 487 (1941).

34304 U.S. 64 (1938).

${ }^{35}$ See Restatement (Second) of Conflict of Laws $\S 98$ (1971); Restatement (SECOND) OF JudGMENTs § 45 (Tent. Draft No. 1, 1973).

Traditionally, discussions of the treatment of foreign judgments in the federal courts 
district court went so far as to assume that Texas public policy was relevant in a suit on a Mexican award of attorney's fees, and proceeded to enforce the judgment as not inconsistent with that policy. ${ }^{36}$

These decisions could have set the stage for the wholesale application of state law to the enforcement of foreign judgments. It took twenty-five years, however, for a federal court to interpret Erie/Klaxon as requiring this result. ${ }^{37}$ The delay was due more to the nature of the cases raising the issue of prior foreign adjudication than to any lack of judicial perception. The great majority of post-Klaxon foreign judgment cases required the courts to resolve the recognition question in the context of federal question litigation; ${ }^{38}$ several of the non-federal question cases were decided on grounds that did not require the courts to

have revolved around the controversial 1895 case of Hilton v. Guyot, 159 U.S. 113 (1895). In that case a French citizen, as plaintiff, recovered judgment against an American citizen in a French court, and subsequently sued in federal court to execute the judgment. After an exhaustive review of the authorities, Mr. Justice Gray enunciated the much-quoted test that:

[W] here there has been opportunity for a full and fair trial abroad before a court of competent jurisdiction, conducting the trial upon regular proceedings, after due citation or voluntary appearance of the defendant, and under a system of jurisprudence likely to secure an impartial administration of justice between the citizens of its own country and those of other countries, and there is nothing to show either prejudice in the court, or in the system of laws under which it was sitting, or fraud in procuring the judgment, or any other special reason why the comity of this nation should not allow it full effect, the merits of the case should not, in an action brought in this country upon the judgment, be tried afresh, as on a new trial or an appeal, upon the mere assertion of the party that the judgment was erroneous in law or in fact.

Id. at 202-03. As the case turned out, however, the Court found such a "special reason" in the fact that France would not give a judgment from the United States more than prima facie effect. Reciprocity, therefore, became the rule for the federal courts. In light of Erie and Klaxon, however, Hilton is no longer controlling. See Domingo v. States Marine Lines, 340 F. Supp. 811,816 n.5 (S.D.N.Y. 1972).

${ }^{36}$ Compania Mexicana Rediodifusora Franteriza v. Spann, 41 F. Supp 907 (N.D. Tex. 1941), aff'd, 131 F.2d 609 (5th Cir. 1942).

${ }^{37}$ Svenska Handelsbanken v. Carlson, 258 F. Supp. 448 (D. Mass. 1966).

${ }^{38}$ The major areas implicated were: admiralty, Petition of Bloomfield S.S. Co., 298 F. Supp. 1239 (S.D.N.Y. 1969), aff'd, 422 F.2d 728 (2d Cir. 1970); Bouas v. Sociedad Maritima San Nicholas, S.A., 252 F. Supp. 286 (S.D.N.Y. 1965), cert."denied, 382 U.S. 1025 (1966); Flota Maritima Browning de Cuba, S.A. v. Motor Vessel Ciudad de la Habana, 218 F. Supp. 938 (D. Md. 1963), aff'd, 335 F.2d 619 (4th Cir. 1964); Perdikouris v. The Liberian S/S Olympos, 185 F. Supp. 140 (E.D. Va. 1960); Applewhaite v. The SS Sunprincess, 150 F. Supp. 827 (S.D.N.Y. 1956); bankruptcy, In re Wyse, 340 F.2d 719 (6th Cir. 1965); Waxman v. Kealoha, 296 F. Supp. 1190 (D. Hawaii 1969); Jones Act (46 U.S.C. $\$ 688$ (1970)), Zorgias v. The SS Hellenic Star, 370 F. Supp. 591 (E.D. La. 1972), aff'd per curiam, 487 F.2d 519 (5th Cir. 1973); Mpiliris v. Hellenic Lines, Ltd., 323 F. Supp. 865 (S.D. Tex. 1970), aff'd mem., 440 F.2d 1163 (5th Gir. 1971); the federal securities laws, Kohn v. American Metal Climax, Inc., 322 F. Supp. 1331 (E.D. Pa. 1971), 
reach the choice of law question. ${ }^{39}$ In 1966, however, a Massachusetts district court enforced a Swedish judgment after giving it only the prima facie effect allowed by century-old Massachusetts cases. ${ }^{40}$ In 1971, the Third Circuit adopted the Pennsylvania rule ${ }^{41}$ in an action on an English default judgment, ${ }^{42}$ and a year later a New York district court noted that "[i]n a diversity suit on a foreign judgment brought in or removed to federal court, state law would plainly apply." 43

The implication of these decisions is clear: The treatment to be accorded foreign judgments is a matter of state law. ${ }^{44}$ There has been some speculation about the development of a federal law of foreign judgment recognition, ${ }^{45}$ but until decisive action is taken, state law will continue to govern the treatment of foreign judgments in American courts.

The question naturally arises, Are foreign judgments based upon arbitral awards under the Convention to be given the same state law treatment? In enacting the legislation implementing the Convention, Congress could have made the treatment of foreign award-based judgments a federal question. ${ }^{46}$ It did not do so. Accordingly, it must be assumed that absent further congres-

modified, 458 F.2d 255 (3d Cir.), cert. denied, 409 U.S. 874 (1972); Kane v. Central Am. Mining \& Oil, Inc., 235 F. Supp. 559 (S.D.N.Y. 1964); and immigration, MacKay v. McAlexander, 268 F.2d 35 (9th Cir. 1959), cert. denied, 362 U.S. 961 (1960); In re Naturalization of Malaszenko, 204 F. Supp. 744 (D.N.J. 1962).

${ }^{39}$ See Harrison v. Harrison, 214 F.2d 571 (4th Cir.), cert. denied, 348 U.S. 896 (1954); Boivin v. Talcott, 102 F. Supp. 979 (N.D. Ohio 1951); Yoder v. Yoder, 24 Ohio App. 2d 71, 263 N.E.2d 913 (1970).

${ }^{40}$ Svenska Handelsbanken v. Carlson, 258 F. Supp. 448 (D. Mass. 1966). In this context "prima facie effect" means that the defendant is entitled to reassert all relevant defenses. Id. at 450 .

${ }^{41}$ In re Estate of Christoff, 411 Pa. 419, 192 A.2d 737 (1963), cert. denied, 375 U.S. 965 (1964).

${ }^{42}$ Somportex Ltd. v. Philadelphia Chewing Gum Corp., 453 F.2d 435 (3d Cir. 1971), cert. denied, 405 U.S. 1017 (1972).

${ }^{43}$ Domingo v. States Marine Lines, 340 F. Supp. 81 I, 816 n.5 (S.D.N.Y. 1972).

${ }^{44}$ See cases cited notes 40-43 supra; British Midland Airways Ltd. v. International Travel, Inc., 497 F.2d 869 (9th Cir. 1974); Island Territory of Curacao v. Solitron Devices, Inc., 489 F.2d 1313 (2d Cir. 1973), cert. denied, 416 U.S. 986 (1974); In re Fotochrome, Inc., 377 F. Supp. 26 (E.D.N.Y. 1974) (dictum); Toronto-Dominion Bank v. Hall, 367 F. Supp. 1009 (E.D. Ark. 1973). But cf. American Express Co. v. Brown, 392 F. Supp. 235 (S.D.N.Y. 1975).

452 A. Ehrenzweig \& E. Jayme, Private International Law § 189-2 (1973); 12 VilL. L. Rev. 618 (1967); see Reese, The Status in This Country of Judgments Rendered Abroad, 50 Colum. L. Rev. 783, 786-88 (1950).

${ }^{46}$ It is doubtful that Erie would stand in the way if Congress enacted such legislation to prevent the subversion of the regulatory scheme embodied in the Convention and implementing legislation, which Congress clearly had the constitutional power to adopt. See note 133 infra. 
sional action, the state law of foreign judgments will govern the treatment of foreign judgments based upon arbitral awards under the Convention. This Comment will therefore continue with a discussion of the treatment of foreign judgments under the laws of the several states to set the stage for an examination of the policies that should control the merger decision.

\section{State Law on Foreign Judgments}

1. Case Law

As a general matter,

Existing case authority ... permits the ... conclusion that judgments of foreign countries will normally be recognized and enforced by American courts. Such a result is required by considerations of justice to the individual litigants or, stated in legal terms, because the principle of res judicata applies to such judgments with equal force as to those of local origin. ${ }^{47}$

In the vast majority of states, ${ }^{48}$ the courts characterize a foreign judgment as conclusive on the merits, thus limiting review to questions of personal and subject matter jurisdiction, fraud, and public policy. ${ }^{49}$

Lack of personal jurisdiction over the defendant in the foreign proceedings is uniformly held to destroy the effect of a foreign judgment. At a minimum, the courts apply fourteenth amendment due process standards; ${ }^{50}$ in many cases, however, the courts apply to foreign judgments state due process concepts which purport to exceed federal requirements. ${ }^{51}$

Lack of subject matter jurisdiction of the foreign court has

${ }^{47}$ Reese, supra note 45, at 800 . Contra, Smit, International Res Judicata and Collateral Estoppel in the United States, 9 U.C.L.A.L. Rev. 44, 48 n.23 (1962).

${ }_{48}$ In a few old but unreversed cases, however, foreign judgments were held to warrant prima facie effect only, thus saving all defenses that could be raised against the original claim. E.g., Kerr, Brown \& Co. v. Condy, 72 Ky. (9 Bush) 372 (1873); Tremblay v. Aetna Life Ins. Co., 97 Me. 547, 55 A. 509 (1903), appeal dismissed, 223 U.S. 185 (1912); see Eastern Townships Bank v. H.S. Beebe \& Co., 53 Vt. 177 (1880).

${ }^{49}$ See, e.g., Northern Alumimum Co. v. Law, 157 Md. 641, 646, 147 A.715, 717 (1929); Dunstan v. Higgins, 138 N.Y. 70, 75, 33 N.E. 729, 730 (1893); Reese, supra note 45 , at 784 .

${ }^{50}$ E.g., Jackson v. Stelco Employees' Credit Union Ltd., 203 So.2d 669 (Fla. Dist. Ct. App. 1967); Wilson v. Gibson, 214 Mo. App. 219, 259 S.W. 491 (1924).

${ }^{51}$ E.g., McEwan v. Zimmer, 38 Mich. 765 (1878); Davidson \& Co. v. Allen, 508 P.2d 6 (Nev. 1973); Schacht v. Schacht, 435 S.W.2d 197 (Tex. Civ. App. 1968); Smith v. Grady, 68 Wis. 215,31 N.W. 477 (1887). 
arisen as a defense to enforcement of a foreign judgment almost exclusively in the divorce context. In most states, the domicile of at least one of the spouses is still the sine qua non of jurisdiction to sever the marital relationship. ${ }^{52}$ Here again, the courts tend to apply their own laws on domicile without regard to the jurisdictional requirements of the foreign law, ${ }^{53}$ although violation of the latter can become an easy threshold ground for nonrecognition. ${ }^{54}$ Outside of the divorce context, some judges hesitate to pass on the competence of a foreign court. ${ }^{55}$ If the issue is clearly drawn, however, the courts will not shrink from adjudicating that question. ${ }^{56}$

Another defense to enforcement of a foreign judgment is extrinsic fraud. The defense encompasses behavior that caused the foreign court to exercise a jurisdiction it otherwise would have denied that it had, ${ }^{57}$ but it can be extended to cover collusive suits. ${ }^{58}$

"Public policy" is a universally recognized exception to the general rule mandating the enforcement of foreign judgments. ${ }^{\mathbf{5 9}}$ The boundaries of this exception, however, are difficult to fix. Arguably included in public policy is the rule against enforcing judgments that are penal in the private international sense, ${ }^{60}$ and courts sometimes subsume valid objections to personal or subject-matter jurisdiction under this rubric. ${ }^{61}$ Also included are violations of "fundamental fairness" or of due process in the

52 See Restatement (Second) of Conflict of Laws $\$$ 70-72 (1971). Contra, Scott v. Scott, 51 Cal. 2d 249, 254, 331 P.2d 641, 644 (1958) (Traynor, J., concurring); Rosenstiel v. Rosenstiel, 16 N.Y.2d 64, 209 N.E.2d 709, 262 N.Y.S.2d 86 (1965), cert. denied, 383 U.S. 943 (1966).

${ }^{53}$ E.g., Schacht v. Schacht, 435 S.W.2d 197 (Tex. Civ. App. 1968); see Ryder v. Ryder, 2 Cal. App. 2d 426, 37 P.2d 1069 (1934); Sargent v. Sargent, 225 Pa. Super. 1, 307 A.2d 353 (1973); In re Estate of Steffke, 222 N.W.2d 628 (Wis. 1974).

${ }^{54}$ See Yoder v. Yoder, 24 Ohio App. 2d 71, 263 N.E.2d 913 (1970).

${ }^{55}$ E.g., In re Estate of Gillies, 8 N.J. 88, 83 A.2d 889 (1951) (Greek adoption decree).

${ }^{56}$ E.g., San Lorenzo Title \& Improvement Co. v. City Mortgage Co., 124 Tex. 25, 73 S.W.2d 513 (1934) (before a Mexican adjudication of title, the land in question had been assigned to Texas under a treaty).

${ }^{57}$ E.g., Parker v. Parker, 155 Fla. 635, 21 So. 2d 141, cert. denied, 326 U.S. 718 (1945) (service upon wife by publication after husband misrepresented his ability to locate her).

${ }^{58}$ Title Ins. \& Trust Co. v. California Dev. Co., 171 Cal. 173, 152 P. 542 (1915).

${ }^{59}$ Nussbaum, Public Policy and the Political Crisis in the Conflict of Laws, 49 Yale L.J. 1027, 1056 (1940).

60 Restatement (Second) of Conflict of Laws § 120, comment $d$ (1971); see Loucks v. Standard Oil Co., 224 N.Y. 99, 120 N.E. 198 (1918) (sister-state).

${ }^{6}$ E.g., In re Estate of Nolan, 56 Ariz. 361, 108 P.2d 388 (1940); Christopher v. Christopher, 198 Ga. 361, 31 S.E.2d 818 (1944); Warrender v. Warrender, 79 N.J. Super. 114, 190 A.2d 684 (App. Div. 1963), aff'd, 42 N.J. 287, 200 A.2d 123 (1964). 
foreign proceedings. ${ }^{62}$ The public policy exceptions uniformly comprehend the illegality of the underlying cause of action, but that the cause no longer exists in the enforcing state is not necessarily conclusive. ${ }^{63}$

\section{State Statutory Law}

State statutes explicitly dealing with the effect of foreign judgments have taken predictable forms. In 1907 California enacted a liberal provision, giving a "final" judgment from a foreign country the same effect it would have in that country, and the same effect as a California judgment, so long as the foreign court had jurisdiction "according to the laws of such country."64 In Montana, Oregon, and Puerto Rico, in rem decrees with jurisdiction are given conclusive effect on title, while in personam judgments are presumptive evidence of a right which can be rebutted only for "a want of jurisdiction, want of notice to the party, collusion, fraud, or clear mistake of law or fact." ${ }^{65}$ In New Hampshire, the legislature has extended to Canadian judgments only "such faith and credit as is given in the courts of the Dominion of Canada ... to the judgments rendered in the courts of New Hampshire,"66 but has left to common law the treatment of judgments from other countries. ${ }^{67}$

The major trend developing in this area of the law is the growing acceptance of the Uniform Foreign Money-Judgments Recognition Act. ${ }^{68}$ To date, the Act has been adopted, essentially intact, by eight states. ${ }^{69}$ As adopted by the Commissioners on

62 In re Estate of O'Dea, 29 Cal. App. 3d 759, 105 Cal. Rptr. 756, 765-66 (C.. App. 1973); In re Davis' Will, 31 Misc. 2d 270, 219 N.Y.S.2d 533 (Sur. Ct. 1961) (judgment rendered after death of party without representation of his estate); Malika Estate, $31 \mathrm{~Pa}$. D. \& C.2d 736 (Orphans' Ct. 1963) (judgment based largely on hearsay); Banco Minero v. Ross, 106 Tex. 522, 172 S.W. 711 (1915) (denial of right to present a defense and denial of appeal on frivolous grounds).

${ }^{63}$ Neporany v. Kir, 5 App. Div. 2d 438, 173 N.Y.S.2d 146 (1958) (seduction and criminal conversation).

${ }^{64}$ Act of Mar. 11, 1907, ch. 178, \& 1, [1906] Cal. Stat. 206 (repealed 1974). The same statute is in force in the Canal Zone and Guam. C.Z. Code tit. 5, $\$ 3198$ (1963); GuaM Code Civ. Proc. \$ 1915 (1970).

${ }_{65}$ Mont. Rev. Codes AnN. $\$ 93-1001-27$ (1964); Ore. Rev. Stat. $\$ 43.190$ (1973);

P.R. LAWS ANN. tit. 32, $\$ 1800$ (1968).

${ }^{66}$ N.H. Rev. Stat. ANN. \& 524:11 (Supp. 1973).

${ }^{67}$ See Stavrelis v. Zacharias, 79 N.H. 146, 106 A. 306 (1919); MacDonald v. Grand Trunk Ry., 7 I N.H. 448, 52 A. 982 (1902); Robinson v. Prescott, 4 N.H. 450 (1828).

68 9B UNIFORM LAwS ANN. 64 (West 1966).

${ }^{69}$ Alaska Stat. $\$ \$ 09.30 .100-.180$ (1973); Cal. Civ. Pro. Code $\$ \S 1713-1713.8$ (West 1972); Ill. Ann. Stat. ch. 77, §§ 121-29 (Smith-Hurd 1966); MD. AnN. Code, 
Uniform State Laws, the act applies to foreign money judgments which are "final and conclusive and enforceable where rendered" despite pending or available appeals. ${ }^{70}$ The judgments are enforced in the same way as sister-state decrees, ${ }^{71}$ unless the foreign court acted in violation of due process, or without personal or subject-matter jurisdiction, in which case the judgment is not conclusive. ${ }^{72}$ The judgment "need not be recognized" if it was rendered without adequate notice, was obtained by fraud, was based on a cause of action repugnant to the state's public policy, conflicted with another conclusive decree, was rendered despite an agreement between the parties providing another means of settlement, or was rendered despite forum non conveniens. ${ }^{73}$

\section{The Doctrine of MERger IN THE INTERNATIONAL CONTEXT}

\section{A. In General}

The doctrine of merger and the corresponding doctrine of bar ${ }^{74}$ constitute the fundamental precepts of res judicata, a principle designed "to secure the peace and repose of society by the settlement of matters capable of judicial determination." 75 The principle of merger is well established: "When a valid and final personal judgment is rendered in favor of the plaintiff ... [he] cannot thereafter maintain an action on the original claim or any part thereof, but he can maintain an action upon the judgment ...."76 The doctrine is part of the common law of every American jurisdiction except Louisiana, where res judicata is purely statutory. ${ }^{77}$

When a foreign judgment is involved, however, the symmetry of the common law breaks down. In 1809, an English

Courts \& Judicial Proceedings $\$ \$ 10-701$ to -709 (1974), reenacting MD. ANn. Code art. 35, §§ 53A-I (1971); Mass. ANn. Laws ch. 235, § 23A (1974); Mrch. Comp. Laws ANN. $\S \S 691.1151-.1159$ (1968); N.Y. CIv. PRAC. Law $\$ \S 5301-09$ (McKinney Supp. 1974); OkLa. Stat. ANN. tit. 12, §§ 710-18 (Supp. 1974).

${ }^{70}$ UnIForm FoREIGN MONEY JUdGMENTS ReCOGNITION ACT $\S 2$.

${ }^{71}$ Id. $\S 3$.

${ }^{72} I d . \S 4(\mathrm{a})$.

${ }^{73} I d . \S 4(\mathrm{~b})$.

74 Restatement (Second) of Judgments $\$ \$ 47,48$ (Tent. Draft No. 1, 1973).

${ }^{75}$ Southern Pac. R.R. v. United States, 168 U.S. 1, 49 (1897).

${ }^{76}$ Restatement (SECOND) of Judgments $\S 47$ (Tent. Draft No. 1, 1973).

${ }^{77}$ LA. Crv. Code ANn. art. 2286 (West 1973). The Louisiana courts seem to think this makes a difference. See, e.g., Durmeyer v. Streiffer, 215 La. 586, 41 So. 2d 226 (1949). 
court reasoned that because a foreign judgment is only prima facie evidence of a debt, the underlying claim could not be merged into it. ${ }^{78}$ The plaintiff, therefore, could elect to sue on his original cause of action without regard to the domestically applicable doctrine of merger. This exception to the general rule eventually attained currency in both Canada ${ }^{79}$ and the United States. ${ }^{80}$

When foreign judgments began to be given more than prima facie effect, the non-merger rule naturally came under attack: ${ }^{81}$ Cessante ratione legis, cessat et ipsa lex. ${ }^{82}$ Several states have clearly rejected the non-merger rule for essentially this reason, ${ }^{83}$ and an English judge has strongly questioned the continuing logic or vitality of the rule in his country. ${ }^{84}$ Although some courts continue to utilize a non-merger point of view, ${ }^{85}$ merger may well be on its way to becoming the favored position.

\section{B. The Merger Doctrine in the Context of Foreign Judgments Based upon Arbitral Awards Under the Convention}

In determining whether to apply the merger doctrine to foreign judgments based upon arbitral awards, courts can proceed in three directions. First, the courts could apply the merger rule in all cases in order to vindicate the underlying policy of the rule. Second, the courts could use traditional conflict of laws analysis; the rules governing the preclusive effect of a foreign judgment would be the rules governing judgments in the rendering forum. Under this approach, if the judgment were

${ }^{78}$ Hall v. Odber, 103 Eng. Rep. 949 (K.B. 1809).

${ }^{79}$ E.g., Clergue v. Humphrey, 31 Can. S. Ct. 66 (1900).

${ }^{80}$ Swift v. David, 181 F. 828 (9th Cir. 1910); New York, L.E. \& W.R.R. v. McHenry, 17 F. 414 (S.D.N.Y. 1883); Tourigny v. Houle, 88 Me. 406, 34 A. 158 (1896); Wood v. Gamble, 65 Mass. (11 Cush.) 8 (1853) (dictum); MacDonald v. Grand Trunk Ry., 71 N.H. 448, 52 A. 982 (1902); Eastern Townships Bank v. H.S. Beebe \& Co., 53 Vt. 177 (1880).

${ }^{81}$ E.g., G. Cheshire, Private International Law 538 (7th ed. 1965); A. Ehrensweig \& E. Jayme, supra note 45, at \& 195-3; H. Read, Recognition and ENFORCEMENT OF FOREIGN JUDGMENTS 117-21 (1938).

${ }^{82}$ The reason of the law ceasing, the law itself also ceases.

${ }^{83}$ Alaska Commercial Co. v. Debney, 2 Alas. 303 (1904), rev'd on other grounds, $144 \mathrm{~F}$. 1 (9th Cir. 1906); Baker v. Palmer, 83 Ill. 568 (1876); Jones v. Jamison, 15 La. Ann. 35 (1860); Swedish Am. Nat'l Bank v. Dickinson Co., 6 N.D. 222, 69 N.W. 455 (1896); Smith v. Grady, 68 Wis. 215,31 N.W. 477 (1887).

${ }^{84}$ Carl Zeiss Stiftung v. Rayner \& Keeler Ltd. (No. 2), [1967] A.C. 853, 966 (1966) (Lord Wilberforce).

${ }^{85}$ See Sargant v. Monroe, 268 App. Div. 123, 49 N.Y.S.2d 546 (1944); Oilcakes \& Oilseeds Trading Co. v. Sinason-Teicher Inter Am. Grain Corp., 9 Misc. 2d 651, 170 N.Y.S.2d 378 (Sup. C. 1958), modified, 7 App. Div. 2d 977, 183 N.Y.S.2d 838 (1959), aff'd mem., 8 N.Y.2d 852, 168 N.E.2d 708, 203 N.Y.S.2d 904 (1960). 
rendered in a civil law country, the underlying cause of action would not be merged into the judgment because common law merger is alien to the civil law system. ${ }^{86}$ If the judgment were rendered in a common law country, the doctrine of merger would be applicable. Third, the courts could apply the nonmerger rule to foreign judgments based upon arbitral awards under the Convention. The remainder of this Comment will argue that this last approach, as a matter of policy, is the correct one.

IV. The Justification for Applying the Non-Merger Rule to Foreign Judgments Based Upon Arbitral Awards Under THE Convention

\section{A. The Law Controlling the Merger Question}

Before proceeding with a discussion of the policy reasons for refusing to merge arbitral awards into foreign judgments based thereon, it is appropriate to determine whether resolution of this merger question is a matter of state or federal law. In fact, the merger decision is a federal question.

On the surface, this conclusion may seem anomalous because the merger question is incident to the effect of a foreign judgment in the United States, which is in turn a matter of state law. ${ }^{87}$ If the plaintiff in a diversity case sues in federal court on the judgment alone, ${ }^{88}$ the application of federal law to any aspect of the case would seem to be a clear violation of Erie R.R. $v$. Tompkins $^{89}$ and Klaxon v. Stentor Electric Manufacturing Co. ${ }^{90}$ The merger decision, however, is an essential step in resolving the underlying jurisdictional issues in cases involving foreign judgments based upon arbitral awards under the Convention. As such, merger must be a federal question. To take the clearest example, if the plaintiff sues on the award under the federal district court's original jurisdiction of actions under the Convention, ${ }^{91}$ and alternatively raises the judgment on pendent jurisdiction because the award is for less than ten thousand dollars, then two federal questions are squarely raised. Do the two

\footnotetext{
${ }^{86}$ A. Nussbaum, Principles of Private International Law $\$ 23$, at 245 (1943).

${ }^{87}$ See notes 33-46 supra \& accompanying text.

8828 U.S.C. \& 1332 (1970).

89304 U.S. 64 (1938).

90313 U.S. 487 (1941).

919 U.S.C. $\S 203(1970)$.
} 
claims partake of "a common nucleus of operative facts"92 so as to make pendent jurisdiction available? Does the federal claim "have substance sufficient to confer subject matter jurisdiction on the court?"93 If either of these questions is answered in the negative, then the federal court is without jurisdiction to hear the state claim. Merger necessarily enters into the resolution of the second issue because if the federal claim is merged into the pendent claim, then the federal claim is not only insubstantial, but nonexistent. Since the merger issue must be settled to determine the jurisdiction of the district court, the court has the power-and the duty-to decide the issue by federal standards. ${ }^{94}$

To illustrate further, suppose the plaintiff sues on both claims but gives each an independent jurisdictional basis because the award exceeds ten thousand dollars. In this situation the court would retain jurisdiction irrespective of the outcome of the merger decision, but the nature of its jurisdiction would change, and with it the applicable law. Such a potent issue should certainly be resolved by uniform federal standards. ${ }^{95}$ Furthermore, the court would be deciding whether a treaty applies; if treaties raise federal questions, so must issues of their applicability. ${ }^{96}$

Because the merger decision is a federal question, the federal courts have the option of choosing an approach to the merger question not heretofore discussed-application of the forum state's rule governing the merger of foreign judgments. This approach, however, like the two other approaches that reject non-merger-application of the merger rule in all cases and use of conflict of laws analysis-suffers from serious weaknesses.

\section{B. Weaknesses of the Three Approaches That Reject Non-Merger}

As a first approach to the merger question, the district court could look to the law of the forum state on the merger of foreign judgments. Although it is under no constitutional compulsion to do so, the court may decide that, as a matter of comity in its relationship to the state courts, it should apply the state rule when no overarching federal standard exists. In the early stages of litigation under the Convention this is an understandable re-

${ }^{92}$ United Mine Workers of America v. Gibbs, 383 U.S. 715, 725 (1966).

${ }^{93}$ Id.

${ }^{94}$ See C. Wright, Handbook of the Law of Federal Courts $\$ 16$ (2d ed. 1970); $c f$. Stifel v. Hopkins, 477 F.2d 1116, 1120 (6th Cir. 1973).

${ }^{95} C f$. Williams v. Ocean Transp. Lines, Inc., 425 F.2d 1183 (3d Cir. 1970).

${ }^{96}$ See generally Friendly, In Praise of Erie-And of the New Federal Common Law, 39 N.Y.U.L. REv. 383 (1964). 
sponse; after all, the implementing legislation appears to give the state and federal courts concurrent jurisdiction, ${ }^{97}$ and a uniform rule within the forum state is therefore necessary. As a rule to be followed throughout the federal system, however, this approach is inconsistent with the United States' treaty commitments.

In acceding to the Convention, the United States did not represent to the other contracting states that state law was at all relevant to their awards. The Convention, apparently on the urging of Australia, ${ }^{98}$ includes a "federal or non-unitary state" clause that allows a country such as the United States to accede without violating internal constitutional restraints on the exercise of its national power. ${ }^{99}$ If the United States had availed itself of this article, the federal government would have been bound only to the extent of its "legislative jurisdiction" and would have been required to "bring such articles with a favourable recommendation to the notice of the appropriate authorities of constituent states . ..."100 The United States thus could have involved state law in the manner provided for in the Convention, but did not. The possible negative impact of this approach on the legitimate expectations of foreign participants in arbitration proceedings could seriously undermine the chances of achieving the goals that motivated the United States' accession to the Convention. Accordingly, this approach should be rejected.

As a second approach to the merger question, the courts could decide to apply the common law merger doctrine whenever that doctrine would be applicable. This response ensures the uniformity lacking in the state law approach, but in so doing, violates the Convention by imposing on the enforcement of foreign arbitral awards conditions "substantially more onerous" than those imposed on domestic awards. ${ }^{101}$ These conditions result from the full faith and credit doctrine. A domestic award reduced to judgment is readily enforceable qua judgment. A foreign award-based judgment, however, being unprotected by the full faith and credit clause, ${ }^{102}$ may not be enforceable in a given state; if this is the case, the court would probably turn to an examination of the award itself. ${ }^{103}$ As a result of this process,

979 U.S.C. $\$ 203$ (1970).

$98 \mathrm{G}$. HAIGHT, supra note 7 , at 80-83.

${ }^{99}$ Convention, art. XI.

${ }^{100} \mathrm{Id}$.

101 Convention, art. III.

102 See Restatement (Second) of Conflict of Laws $\$ 98$, comment $b$ (1971).

${ }^{103}$ See text accompanying notes 107-09 infra. 
the recognition and enforcement of the plaintiff's award would be unnecessarily protracted. To prevent this imposition of the "more onerous conditions" that the United States is committed to avoid, the pure merger approach should be rejected.

As a third approach to the merger question, the courts could follow the conflict of laws analysis and determine the merger issue by the law of the nation whose judgment is involved. ${ }^{104}$ If a common law judgment is involved, however, this approach does not address the problems raised in the remainder of this Comment, and could in fact obscure their proper resolution by its compelling simplicity. ${ }^{105}$ Moreover, if as a matter of policy it is undesirable to allow state law to determine the nature of a federal court's jurisdiction, ${ }^{106}$ it is at least equally undesirable to allow foreign law to accomplish the same result.

\section{Advantages of Non-Merger}

The advantages of the non-merger approach are best classified in terms of the particular situation facing a court. The reason for this is that although non-merger is generally to be preferred, it is not always to be preferred for the same reason. The discussion that follows, therefore, is divided into four categories representing the four possible situations with which a court might be faced: (1) an enforceable award accompanied by an unenforceable judgment; (2) an unenforceable award accompanied by an enforceable judgment; (3) an enforceable award accompanied by an enforceable judgment; and (4) an unenforceable award accompanied by an unenforceable judgment.

\section{Enforceable Award Accompanied by Unenforceable Judgment}

When the court is faced with an enforceable award accompanied by an unenforceable judgment, a decision to apply the merger doctrine under any of the three merger approaches ${ }^{\mathbf{1 0 7}}$ should cause the court to refuse to merge the award into the judgment. ${ }^{108}$ For this reason, the non-merger approach is clearly

${ }^{104}$ See text accompanying note 86 supra.

${ }^{105}$ At least one court has been impelled in this direction. Island Territory of Curacao v. Solitron Devices, Inc., 489 F.2d 1313, 1318 n.4 (2d Cir. 1973), cert. denied, 416 U.S. 986 (1974).

${ }^{106}$ See text accompanying notes 87-96 supra.

${ }^{107}$ The term "merger approach" is used to describe any of the three approaches rejecting non-merger described in text accompanying notes 97-106 supra.

${ }^{108}$ Restatement (Second) of Judgments \$ 47 (Tent. Draft No. 1,1973 ). It is as- 
preferable. Even if the court following a merger approach correctly applies the merger doctrine, non-merger, because it permits the court to enforce the award irrespective of the judgment, saves the court the time that it takes to determine that the judgment is unenforceable. Moreover, if the court in following a merger approach analyzes the merger issue incorrectly ${ }^{109}$ and merges the award into the unenforceable judgment, then the court strips the plaintiff of his rights for no valid reason. Nonmerger prevents this unconscionable result.

\section{Unenforceable Award Accompanied by Enforceable Judgment}

A court faced with an unenforceable award accompanied by an enforceable judgment is confronted with the difficult issue of the proper accommodation of federal and state interests in the context of the existing division of competence between federal and state courts. The definition of an enforceable foreign award is a matter for federal law alone; ${ }^{110}$ the definition of an enforceable foreign judgment is a matter for state law alone. ${ }^{111}$ The question in the instant case is whether a plaintiff can be permitted to recover under state law when the policy of the federal law would require recovery to be denied.

a. The Likelihood That a Foreign Judgment Will Be Enforceable Under State Law When the Underlying Arbitral Award is Unenforceable Under Federal Law

An action on a foreign judgment is governed by state law. ${ }^{112}$ Most states give foreign judgments conclusive effect, recognizing as defenses only (1) that the foreign court lacked jurisdiction, (2) that the proceedings were tainted by extrinsic fraud, and (3) that the underlying cause of action is repugnant to the public policy

sumed that in limiting the application of the merger doctrine to "valid and final" judgments, $i d$., the term "valid" is intended to mean "enforceable."

${ }^{109} \mathrm{~A}$ court could easily analyze the issue incorrectly by failing to appreciate the breadth of the term "valid judgment" as used in the merger doctrine, text accompanying note 76 supra; the court could interpret the term to be used in the sense that sister-state judgments are "valid" under the full faith and credit clause when not violative of due process. See Alaska Commercial Co. v. Debney, 2 Alas. 303 (1904), rev'd on other grounds, 144 F. I (9th Cir. 1906).

${ }^{110}$ See note 13 supra \& accompanying text.

${ }^{11}$ See notes $33-46$ supra \& accompanying text.

${ }^{112} I d$. 
of the state. ${ }^{113}$ The treatment of arbitral awards under the Convention, on the other hand, is a matter of federal law, which recognizes a limited number of defenses to enforcement including the defense that enforcement of the award would be contrary to federal public policy. ${ }^{114}$ If it can be shown, therefore, that the public policies that impeach a judgment under state law bear no relationship to those that impeach an arbitral award under federal law, the likelihood that a foreign judgment will be enforceable under state law when the underlying arbitral award is unenforceable under federal law will be established. The requisite lack of relationship is easily shown.

In the federal-state context, variations in legislative competence will in themselves lead to differing definitions of what a government and its courts simply will not do as a matter of public policy. Some matters the states leave to Caesar because they must, others because they have no interest in them. Even where federal and state interests coincide, it is within the power of each state to determine the degree of importance it will attach to its interests, without reference to the importance the federal government places on its corresponding concerns. As a theoretical matter, therefore, uniformity of response will at best be fortuitous.

In applying the Federal Arbitration Act of $1925,{ }^{115}$ the courts have isolated a number of federal legislative interests which they consider inappropriate for settlement by arbitration: ${ }^{116}$ issues under the securities laws, ${ }^{117}$ antitrust claims, ${ }^{118}$

${ }^{113}$ See text accompanying notes 47-73 supra.

${ }^{114}$ See notes 9-11 supra \& accompanying text.

1159 U.S.C. $\$ \S 1-14(1970)$.

1169 U.S.C. $\S 208$ (1970) allows the incorporation of such precedent into the law governing foreign awards. Because such exceptions are mandated in article $V$ of the Convention, they are "not in conflict with ... the Convention as ratified by the United States." Id. But see Scherk v. Alberto-Culver Co., 417 U.S. 506 (1974).

117 Wilko v. Swan, 346 U.S. 427 (1953) (Securities Act of 1933, 15 U.S.C. $\$ \S 77 a-a a$ (1970)); Macchiavelli v. Shearson, Hammill \& Co., 384 F. Supp. 21 (E.D. Cal. 1974) (Securities Exchange Act of 1934, 15 U.S.C. $\$ \$ 78$ a to hh-1 (1970)); Reader v. Hirsch \& Co., 197 F. Supp. 111 (S.D.N.Y. 1961) (1934 Act).

${ }^{118}$ Cobb v. Lewis, 488 F.2d 41 (5th Cir. 1974); Helfenbein v. International Indus., Inc., 438 F.2d 1068 (8th Cir.), cert. denied, 404 U.S. 872 (1971); Associated Milk Dealers, Inc. v. Milk Drivers Local 753, 422 F.2d 546 (7th Cir. 1970); A. \& E. Plastik Pak Co. v. Monsanto Co., 396 F.2d 710 (9th Cir. 1968); American Safety Equip. Corp. v. J.P. Maguire \& Co., 391 F.2d 821 (2d Cir. 1968). Without this exception, Judge Feikens' tortuous decision in Overseas Motors, Inc. v. Import Motors Ltd., 375 F. Supp. 499 (E.D. Mich. 1974), appeal docketed, No. 74-1651, 6th Cir., June 19, 1974, would have been unnecessary. 
and patent validity. ${ }^{119}$ These prohibitions generally do not apply to submissions to arbitration after the claim has arisen, but serve to render such claims nonarbitrable pursuant to a broad, preexisting arbitration clause. ${ }^{120}$ As national priorities change, it can be expected that Congress or the courts will find that other federal interests are so compelling that they require a protection which the private vindication of contractual rights through arbitration will provide imperfectly at best, and will frustrate at worst. ${ }^{121}$

To be sure, some states have echoed federal law in exempting claims under local blue sky or antitrust statutes from arbitration. ${ }^{122}$ The importance of this congruity is negligible, however, because (1) the states are under no compulsion to follow federal law in the interpretation of their own statutes; (2) no necessary correlation exists between these exceptions and the public policy objections to the enforcement of a foreign judgment; and (3) even assuming such a correlation, it is highly improbable that the state whose law is used to validate the judgment would have had jurisdiction over the transaction alleged to violate local law. It is so easy to serve a corporate defendant in a state that had no contact with the transaction in question that to depend on state law to reach the federal result would be irrational.

The courts, therefore, are likely to be faced with foreign judgments that are enforceable under state law but that are based upon arbitral awards unenforceable as a matter of federal law. Several policy considerations point toward a resolution of the problem.

119 Beckman Instruments, Inc. v. Technical Dev. Corp., 433 F.2d 55 (7th Cir. 1970), cert. denied, 401 U.S. 976 (1971); Leesona Corp. v. Cotwool Mfg. Corp., 204 F. Supp. 141 (W.D.S.C. 1962), aff'd, 315 F.2d 538 (4th Cir. 1963).

${ }^{120}$ See, e.g., Coenen v. R.W. Pressprich \& Co., 453 F.2d 1209 (2d Cir.), cert. denied, 406 U.S. 949 (1972) (securities \& antitrust issues); Moran v. Paine, Webber, Jackson \& Curtis, 389 F.2d 242 (3d Cir. 1968) (Securities Act of 1933, 15 U.S.C. $\$ \$ 77 a-a a(1970)$, \& Securities Exchange Act of 1934, 15 U.S.C. \$§ 78a to hh-1 (1970)).

${ }^{121}$ Two such areas that come to mind immediately are energy allocation and the protection of the environment.

${ }^{122}$ E.g., Shearson, Hammill \& Co. v. Vouis, 247 So. $2 d 733$ (Fla. Dist. Ct. App.), cert. denied, 253 So. 2d 444 (Fla. 1971) (securities); Aimcee Wholesale Corp. v. Tomar Prods., Inc., 21 N.Y.2d 621, 237 N.E.2d 223, 289 N.Y.S.2d 968 (1968) (antitrust); see Foreman v. Holsman, 10 Ill. 2d 551, 141 N.E.2d 31 (1957) (invalid release from blue sky liability). But cf. Mills v. Robert W. Gottfried, Inc., 272 So. 2d 837 (Fla. Dist. Ct. App. 1973). 


\section{b. The Policy Considerations}

In Island Territory of Curacao v. Solitron Devices, ${ }^{123}$ the Second Circuit was faced with a judgment that was enforceable under state law, but that was based on an arbitral award arguably unenforceable as a matter of federal law. Plaintiff was the successful party in a Curacaoan arbitration. Before coming to the United States for enforcement of the arbitral award, plaintiff sought enforcement in the Curacaoan courts and obtained a judgment on his award. When he brought suit in federal district court, plaintiff thus sought enforcement of either the award or the Curacaoan judgment.

Under the view of the case taken by the court, it was necessary to decide whether an award-based judgment could be enforced under state law if the underlying award were unenforceable as a matter of federal law. The court pointed out that "the policy of New York State to recognize foreign judgments 'prevails in the absence of interference with the federal regulatory scheme" "124 and, finding no such interference, held that an award-based judgment could be enforced notwithstanding the invalidity of the award.

The court's failure to find interference with the federal regulatory scheme was based upon its observation that "the Convention on Recognition itself and its enforcing legislation go only to the enforcement of a foreign arbitral award and not to the enforcement of foreign judgments confirming foreign arbitral awards ...."125 By looking only to words rather than effects, the court overlooked a blatant source of interference.

In implementing the Convention, Congress certainly did not intend to arrogate to the federal government powers that it did not otherwise possess. ${ }^{126}$ By explicitly creating federal question jurisdiction over foreign arbitral awards, ${ }^{127}$ however, Congress clearly intended that the arbitrability and public policy exceptions to enforcement would be defined by federal substantive

${ }^{123} 489$ F.2d 1313 (2d Cir. 1973).

${ }^{124} \mathrm{Id}$. at 1319 (quoting Merrill, Lynch, Pierce, Fenner \& Smith, Inc. v. Ware, 414 U.S. 117,140 (1973)).

$125 \mathrm{Id}$.

126 Senate Comm. On Foreign Relations, Foreign Arbitral Awards, S. Rep. No. 91-702, 91st Cong., 2d Sess. 10 (1970).

1279 U.S.C. \& 203 (1970). 
law. If the courts were permitted to enforce award-based judgments notwithstanding the unenforceability of the underlying award, then the holder of an unenforceable award would be encouraged to evade the federal standards by executing his award abroad. In this respect, the treatment of foreign arbitral awards would for all purposes except nomenclature become a matter of state, not federal, law. As a matter of policy, therefore, it follows, notwithstanding Solitron, that the courts should not willingly become partners in the subversion of a federal regulatory scheme by enforcing foreign judgments based upon invalid arbitral awards.

\section{c. A Means of Preventing Subversion of the Federal Regulatory Scheme}

The supremacy clause of the Constitution provides a means for the courts to prevent the subversion of the federal regulatory scheme. In all jurisdictions, the illegality of the underlying cause of action is a recognized ground for nonenforcement of a foreign judgment; ${ }^{128}$ the Uniform Foreign Money Judgments Recognition Act acknowledges that a foreign judgment need not be enforced when "the [cause of action] . . . on which the judgment is based is repugnant to the public policy of [the] state." 129 The supremacy clause injects federal policy into state public policy so that an award is repugnant to state public policy if repugnant to federal policy.

In Mondou v. New York, N.H. $\mathcal{E}^{2}$ H.R.R. ${ }^{130}$ the state of Connecticut refused to enforce rights arising under the Federal Employers' Liability Act, contending that enforcement of the congressionally created right was contrary to Connecticut policy. The Supreme Court refuted the basis of this contention:

When Congress, in the exertion of the power confided to it by the Constitution, adopted that Act, it spoke for all the people and all the States, and thereby established a policy for all. That policy is as much the policy of Connecticut as if the act had emanated from its own legislature, and should be respected accordingly in the courts of the State. ${ }^{131}$

${ }^{128}$ See note 63 supra \& accompanying text.

129 UNIFORM Foreign MONEY JUdGMENTS ReCOgNition ACT $\$$ 4(b)(3).

130223 U.S. 1 (1911).

${ }^{131} \mathrm{Id}$. at 57. 
Similarly, when Rhode Island refused to enforce a particular federal law on the ground that the law violated the state's policy against enforcing "penal" statutes not its own, the Court responded simply that "the policy of the federal Act is the prevailing policy in every state."132

Because an arbitral award can be invalid only if it violates the federal policy expressed in the treaty and implementing legislation, an award invalid under federal law is, by virtue of the supremacy clause, repugnant to the policy of all states. By incorporating the federal grounds for denying enforcement of awards into the state public policy grounds for denying enforcement of an award-based judgment, the supremacy clause prevents subversion of the federal regulatory scheme. ${ }^{133}$

\section{d. The Role of Non-Merger}

In order to illustrate the role of non-merger in the supremacy clause approach proposed above, it is instructive to consider the procedural setting in which the pertinent defense will be raised given the applicability of the merger doctrine. The plaintiff will enter an American court, assumed here to be a

132 Testa v. Katt, 330 U.S. 386,393 (1947).

${ }^{133}$ An alternative approach to the problem of award-based judgments begins with the recognition that if the judicial treatment prescribed by the treaty for arbitral awards was also applicable to foreign judgments on such awards as well, the divergence between state and federal law would not result in the subversion of the federal scheme since, under the supremacy clause, the treaty would take precedence over inconsistent state law. See Ware v. Hylton, 3 U.S. (3 Dall.) 198, 236-37 (1796) (opinion of Chase, J.). One commentator, desiring to protect the integrity of the federal scheme, has attempted to invoke this principle by arguing that the Convention is applicable to foreign judgments on arbitral awards because its draftsmen intended it to apply to such judgments. 5 GA. J. INT'L L. \& CoMP. L. 264 (1975). This argument is seriously impaired, however, by the natural inference, from the treaty's failure to discuss the treatment to be given judgments on arbitral awards, that the draftsmen, far from intending the treaty to resolve the problem, never even considered it. Accordingly, this method of vindicating the federal interest must be rejected.

It should be pointed out that the problems posed by judgments on arbitral awards can be resolved independent of the courts, either through a new trëaty governing the treatment of foreign judgments on arbitral awards, or through legislation to the same effect under the existing Convention. Such action would preempt the field so as to invalidate the state law of foreign judgments as applied to judgments on arbitral awards under the treaty.

A treaty cannot be the supreme law of the land, that is, of all the United

States, if any act of a state legislature can stand in its way ... . The people of America have been pleased to declare that ... laws of any of the states, contrary to a treaty, shall be disregarded.

Ware v. Hylton, supra at 236-37 (opinion of Chase, J.). 
state court, ${ }^{134}$ seeking enforcement of an award-based foreign judgment in his favor. In his defense, the defendant will raise the state's public policy exception to enforcement of foreign judgments arguing (1) that the underlying award is invalid under federal law; (2) that the award is accordingly repugnant to the policy expressed in the treaty and implementing legislation; (3) that by virtue of the supremacy clause the award is repugnant to the public policy of the state; and therefore, (4) that the state's public policy exception to enforcement is applicable. It is then open to the plaintiff to argue (1) that the doctrine of merger operates to bar the unsuccessful defendant from raising new defenses to the suit on the award in later actions between the parties; (2) that defendant's argument that the award is invalid is a defense to the suit on the award; and therefore, (3) that the defendant is estopped by the doctrine of merger from raising the invalidity of the award.

Whether a state court would accept plaintiff's argument is unclear. Presumably, the doctrine of merger should operate to preclude the defendant from raising only those defenses that were, or "might have been," raised in the prior litigation. ${ }^{135} \mathrm{Be}$ cause the United States' defenses to the enforcement of the award probably were not available in the foreign tribunal, it is at least arguable that the United States' defenses were not among those that "might have been" raised in the action on the award, and thus, that merger does not preclude the defendant from raising these defenses in the action on the judgment. It must be emphasized, however, that once the federal courts decide that the doctrine of merger applies to arbitral awards and judgments based thereon, the substance of the merger doctrine is a matter of state law. Accordingly, a state could declare that its merger doctrine prevents the defendant from raising in the action on the judgment even those defenses that he could not have raised in the action on the award. It is also possible that a court could fail to appreciate the subtleties of merger and simply accept the plaintiff's description of the merger doctrine. In either of these situations the result of a merger approach would be the subversion of the federal regulatory scheme. ${ }^{136}$

${ }^{134}$ Because of Erie R.R. v. Tompkins, 304 U.S. 64 (1938), the analysis should be no different if the plaintiff sues in federal court in a diversity case.

${ }^{135}$ See, e.g., Cromwell v. County of Sac, 94 U.S. 351, 352-53 (1876).

${ }^{136}$ Of course the subversion would not necessarily continue ad infinitum. If a state supreme court were to apply the merger doctrine to defenses that could not have been 
Under the non-merger rule, the federal regulatory scheme would be protected even in these situations. It is the essence of non-merger that neither the arbitral award nor the defenses to its enforcement are extinguished. It follows, therefore, that the defendant could not be estopped from proving the invalidity of the award under federal law, and thus would be able to invoke the public policy ground for nonenforcement of a foreign judgment. Accordingly, the policy considerations discussed above dictate that non-merger be preferred to the merger approaches when the court is faced with an unenforceable award accompanied by an enforceable judgment.

\section{Unenforceable Award Accompanied by an Unenforceable Judgment}

In the case of an unenforceable award accompanied by an unenforceable judgment, the non-merger approach is to be preferred as a matter of effective judicial administration. If the plaintiff sues on his judgment alone, then non-merger and merger take the same amount of judicial time. If, however, the plaintiff sues on his award, or both judgment and award, nonmerger can result in a significant saving of time. If the doctrine of merger is applicable, the court will look first to the validity of the judgment. If the defendant has more than one defense, the court is likely to decide one or more of the non-public policy defenses before reaching the public policy defense, under which it will find the award to be invalid as a matter of federal law ${ }^{137}$ and, therefore, will hold the judgment unenforceable. Under non-merger, however, the court will look first to the award, and, finding it invalid, will find the judgment invalid. ${ }^{138}$ The difference between merger and non-merger in this situation, then, is that non-merger saves judicial time by avoiding the need to decide unnecessary defenses.

raised in the action on the award and the United States Supreme Court were to review that decision, the Court could prevent the undesired result. It is doubtful that the Court would rewrite the state's merger rule as a matter of federal law; more likely the Court would hold that, if this is what the state means by "merger," it cannot apply the doctrine to foreign arbitral awards where paramount federal interests are involved. See Reconstruction Fin. Corp. v. Beaver County, 328 U.S. 204 (1946) (Pennsylvania's expansive definition of "real property" for tax purposes does not so burden federal ownership of industrial plants as to require a federal definition of that term as used in the federal statute). A failure of the lower federal courts to adopt the non-merger approach could be remedied by the Supreme Court's requiring them to do so.

${ }^{137}$ See text accompanying notes 110-36 supra.

${ }^{138} I d$ 


\section{Enforceable Award Accompanied by Enforceable Judgment}

In the case of an enforceable award accompanied by an enforceable judgment, the non-merger approach is to be preferred as a matter of sound jurisprudence. Non-merger, by forcing the courts to decide the merits of federal defenses, encourages the growth of the common law of arbitral awards and the development of definite standards for measuring future claims.

Under the merger approaches, however, the defendant may be estopped from raising his defenses to the award. ${ }^{139}$ When both award and judgment are enforceable, a court does not subvert the federal scheme by enforcing the judgment and ignoring the award. By doing so, however, the court avoids analyzing the merits of the federal defenses and inhibits the development of the common law of arbitral awards which should supplement the treaty and the implementing legislation. The longer the courts refrain from scrutinizing inadequate defenses by enforcing judgments, the longer it will take to evolve the proper standards for measuring similar claims. Even poor defenses are rejected for a reason, and the reason is the guide to future adjudication without which both the parties and the courts are set adrift.

\section{Gonclusion}

The federal courts will soon be required to determine whether traditional concepts of res judicata are applicable to foreign judgments entered on arbitral awards under the Convention on the Recognition and Enforcement of Foreign Arbitral Awards. Although the issue may, on its face, appear to be procedural underbrush, the courts should not allow this first impression to cause them to overlook the policy implications of the choice. This Comment has attempted to identify the alternatives open to the courts and to outline the policies that should guide their determination. ${ }^{140}$

${ }^{139}$ See text accompanying notes 134-36 supra.

140 Restatement (SeCond) of Judgments $\$ 47$, comment $i$ (Tent. Draft No. 1, 1973) states:

Merger in a judgment on a judgment. When the plaintiff has obtained a judgment against the defendant and brings an action upon the judgment, and obtains a judgment in that action, the first judgment is not merged in the second judgment .... The plaintiff can enforce either judgment ... but satisfaction of one of the judgments operates also as satisfaction of the other.

This rule provides a doctrinal method for arriving at the result advocated by this Comment. Because the purpose of the Convention on Recognition and Enforcement of 
The interest in finality that res judicata protects should not control the treatment of arbitral awards under the Convention. Outweighing that interest are the policies of sound jurisprudence, effective judicial administration, federalism, and simple equity.

Foreign Arbitral Awards is to make arbitral awards as enforceable as judgments, see note 16 supra \& accompanying text, it should not be difficult for a court to deem the award to be a judgment for the purposes of this rule. In this manner, the actual foreign judgment becomes a judgment on a judgment, and, in accordance with well established doctrine, the court can achieve the non-merger result. 